\title{
De la ziaristică la mistică: identitatea creștină a lui Daniil Sandu Tudor
}

Ioana URSU*

Abstract: Inter-war journalist and writer Sandu Tudor (born Alexandru Teodorescu) entered monastic life in the mid-1940s at the monastery of Antim in Bucharest. Known for his controversial inter-war biography (former director of the right-wing newspaper Credința, talented poet and versifier; a dandy, married thrice, actively involved in the literary and cultural debates of the interwar era), monk Alexandru becomes hieromonk Agathon and later on, hieroskemamonk Daniil, retreats at a mountain monastery in the Rarău mountains, experiences political detention twice, and ends up dying in prison. Starting from the radical change in his life represented by monasticism, the present paper proposes to examine Sandu Tudor's/hieroskemamonk Daniil's Christian identity and the way he asserted it, starting with the years spent at the monastery of Antim during the initiation of the Burning Bush group, and until the 1950s, appealing to sources found in the archives of the Securitate, but also to memorialistic literature, as well as some of his writings.

Keywords: Burning Bush, political repression, mysticism, Sandu Tudor manuscripts.

\section{Fragmente biografice, 1949-1962}

Biografia „liderului” asociației Rugul Aprins de la mănăstirea Antim, Sandu Tudor (mai târziu ieroschimonahul Daniil de la

* Doctor în istorie și muzeograf în cadrul Muzeului Naţional al Unirii din Alba Iulia, România. 
Rarău) a fost deseori citată pentru paradoxul ei: un cunoscut ziarist interbelic, controversat pentru pozițiile sale publice și tumultul vieții personale, alege să intre în monahism, ajunge stareț la o mănăstire din vârful munților Moldovei și sfârșește, după două perioade de detenție politică, prin a muri în închisoare.

Pornind de la schimbarea radicală în viața lui Sandu Tudor, monahismul, articolul de față își propune să examineze identitatea creștină a lui Sandu Tudor şi felul în care aceasta s-a afirmat începând cu activitatea de la Antim și în anii '50. Sursele sunt constituite de fragmente din arhiva Securității, dar și de fragmente memorialistice și manuscrise ale lui Sandu Tudor/ieroschimonahul Daniil.

Sandu Tudor intră în mănăstire la Antim ca frate în 1947 („fratele Alexandru”) și este tuns în monahism în 3 septembrie 1948 de mitropolitul Firmilian al Olteniei, devenind monahul Agaton ${ }^{1}$. Nu mult timp după, este hirotonit și așezat tot de Firmilian drept stareț la mănăstirea Crasna din județul Gorj. De acolo va fi arestat, iar detalii despre acest moment găsim într-o notă informativă din 31 iulie 1950, care privește vizita făcută de Mitropolitul Nicolae Bălan al Ardealului, Mitropolitului Firmilian al Olteniei. De aici aflăm că:

\begin{abstract}
„Starețul schitului Crasna din județul Gorj, monahul Agaton Tudor, fostul Sandu Tudor de la mănăstirea Antim din București, pe la începutul lunii iulie se spune că a plecat din mănăstire cu o mașină, însoțit de trei persoane și nu s-a mai întors. Se crede că a fost arestat, spun călugării, că el cât a fost stareț vorbea în biserică și făcea morală cetățenilor în fiecare zi și asemenea puținilor călugări pe care-i avea sub stăpânirea sa. La Mitropolia Olteniei nu se știe nimic oficial despre dispariţia lui Agaton Tudor”2.
\end{abstract}

1 Document din Arhiva Mănăstirii Sihăstria, consultat prin bunăvoința cercetătorului Adrian Nicolae Petcu.

2 Cristina PĂIUȘAN / Radu CIUCEANu, Biserica Ortodoxă Română sub regimul comunist, 1945-1958, vol. I, Bucureşti, Institutul Naţional pentru Studiul Totalitarismului, 2001, p. 197-198. 
De la ziaristică la mistică:

identitatea creștină a lui Daniil Sandu Tudor

După cum indică și nota de mai sus, nici la Crasna, dar nici când era la Antim, Agaton Tudor nu era simpatizat de călugării din obște pentru stilul său vulcanic și predicile dure. Câtă vreme se afla încă la Antim, un călugăr din obște își exprima nemulțumirile într-o notă informativă: „Agaton, fost aviator, marinar, ziarist, fost la Sfântul Munte Atos, acum la bătrânețe a venit la Antim ca să facă «misticism» și ce «misticism» pe pielea altora! Prin predici și conferințe interminabile și prin observații dure și obraznice, chinuiește atât pe călugări cât și pe credincioși ce vin la biserică"’3.

\begin{abstract}
„Agaton vine numai atunci când ține predică și atunci numai la sfârşitul slujbei, lucru care face pe mulţi credincioși să iasă afară din biserică pentru că nu îl pot suferi. Prezența lui produce nervozitate și indispoziție, fiindcă vine ca un procuror şi acuză, pe toată lumea, reieșind că toți sunt greșiţi și numai el este drept. Mulți credincioși și călugări s-au exprimat că mai bine s-ar simți dacă Agaton n-ar mai apărea la Antim. Iată de o săptămână este plecat la Craiova, la Mitropolitul Firmilian cu care are vechi legături și lipsa lui s-a simțit foarte mult, deoarece toată lumea este liniștită și împăcată sufletește că n-are cine-i cicăli”4.
\end{abstract}

În decembrie 1949, de pildă, când Agaton era încă călugăr la Antim și făcea deplasări la Crasna pentru a colabora cu mitropolitul Firmilian la tipărirea unei cărți de rugăciuni ${ }^{5}$, Ghiuș, starețul, îl cheamă înapoi la Antim doar ca să predice, a doua zi urmând să se reîntoarcă la Craiova, ceea ce trezește nemulțumirea unor monahi din obște: „La București a venit numai pentru «predica» ce era programată joi seara. Putea să vorbească și altcineva în locul lui însă preotul Benedict Ghiuș a ținut să vorbească Agaton pe care 1-a chemat telefonic de la Craiova" $"$.

${ }^{3}$ ACNSAS, Fond Informativ, dosar nr. 2214, vol. 2, f. 98.

${ }^{4}$ ACNSAS, Fond Informativ, dosar nr. 2214, vol. 1, f. 463.

${ }^{5}$ ACNSAS, Fond Informativ, dosar nr. 2214, vol. 1, f. 460.

${ }^{6}$ ACNSAS, Fond Informativ, dosar nr. 2214, vol. 1, f. 460-461. 
În iulie 1950, însă, aşa cum am văzut mai sus, Agaton Tudor este arestat. În privința procesului, chiar mitropolitul Firmilian afirma:

„Fostul Mitropolit al Bucovinei, Tit Simedrea, actualmente consilier la Institutul Biblic, afirmă în legătură cu procesul lui Sandu Tudor, fost în ultimul timp ieromonah stareț Agaton Tudor de la schitul Crasna-Gorj, următoarele: «Este limpede că acest proces nu are caracter politic: Sandu Tudor a devenit incomod prin cercul de tineri, pe care i-a strâns în jurul său la mănăstirea Antim. Procesul are deci o semnificație bisericească. Se lovește într-un om al Bisericii. Piesele din dosarul procesului sunt de mult în mâinile lor. L-au scos la iveală acum pentru că vor să-l scoată din circulație pe Sandu Tudor. Comuniștii care au pus la cale procesul sunt niște foști găinari. Tare mă tem că justitiia va fi silită să-1 achite, deoarece martorii propuși au declarat că reclamanții au fost pur și simplu niște hoți și niște găinari și nu muncitori progresiști. Condamnarea lui Agaton Tudor - dacă se va produce - va constitui un nou document despre aşa zisa sinceră colaborare dintre Biserică și regim». Mitropolitul Firmilian Marin a mărturisit că în momentul arestării lui Sandu Tudor, s-a temut foarte mult ca să nu fie amestecat, pentru că $1-a$ protejat și numit stareț, cu tot trecutul său politic, cu toate că avea o dezlegare în acest sens de la Patriarhul Justinian"”.

După doi ani și jumătate de detenție politică la Canal, Agaton Tudor este eliberat, iar în iulie 1953 ajunge la mănăstirea Sihăstria, unde a fost tuns ieroschimonah, primind numele de Daniil. După scurt timp, tot în 1953, a fost mutat la Rarău ca egumen, iar în 1954 a fost numit stareț al schitului ${ }^{8}$.

7 Studiu al D.G.S.P. asupra structurii și activității înalților ierarhi ai Bisericii Ortodoxe Române, 20 august 1950. Cristina PăIUșAn, Radu CiUCEANU, op. cit., p. 200-201.

${ }^{8}$ ACNSAS, Fond Informativ, dosar nr. 2214, vol. 1, f. 96. 
De la ziaristică la mistică:

identitatea creștină a lui Daniil Sandu Tudor

O notă informativă interesantă din dosarele Securității se leagă de proiectul lui Sandu Tudor de a face o mănăstire de intelectuali - bineînțeles, în aceeași idee de continuare a modelului de studiu îmbinat cu rugăciunea iniţiat la Cernăuţi (retragerea spirituală din 1943), Antim (întâlnirile grupului „Rugul aprins”) și Govora (1947, o reuniune similară cu cea de la Cernăuți), dar mai mult, de a-i educa și a-i forma într-o rezistență intelectuală împotriva comunismului. E vorba de un proiect care apare semnalat în detaliu în filele dosarului informativ 211015, care se ocupă cu urmărirea informativă la începutul anilor '50 la mănăstirile Secu, Sihăstria, Slatina și Rarău. Dosarul conține numele ieroschimonahului Daniil (Sandu Tudor), dar și al altor duhovnici cunoscuți: Cleopa Ilie, Arsenie Papacioc, Petroniu Tănase și alții sunt prezenti în acest dosar informativ ${ }^{9}$. În momentul în care se făceau verificări pentru dosarul de urmărire informativă de grup al Rugului Aprins în București (1957), iese la iveală faptul că Sandu Tudor/Daniil era deja „lucrat în acțiune informativă” la Suceava. Astfel, Direcția regională M.A.I. Suceava răspunde Direcției a III-a București, cerând totodată sprijin în vederea unei coordonări mai eficiente a urmăririi informative:

„La ordinul dvs. 341/00.210.332 din 9 ianuarie a.c. [1957] referitor la punerea în supravegherea operativă a lui Sandu Tudor raportăm: susnumitul este lucrat de regiunea Suceava pe bază de acțiune informativă grup pe linia serviciului unu din direcția a III-a deoarece împreună cu alte elemente caută să atragă în schit elemente tinere legionare intelectuali cu care să ducă o luptă activă pe plan ideologic împotriva comunismului, în care scop să-și creeze și un cerc filozofic reacționar. Prin agentura ce lucrează în acțiune care constituia o sarcină permanentă s-au stabilit din timp unele deplasări, lucru ce a făcut să fie pus în supraveghere operativă de două ori. Totuşi, în mai multe rânduri s-a deplasat în alte localități. $\mathrm{Nu}$ a putut fi supravegheat pe motivul că schitul se afla la

\footnotetext{
${ }^{9}$ Care numără 3 volume și peste 1300 de file.
} 
o distanță de $18 \mathrm{~km}$ de orașul Câmpulung, iar agentul nu se afla în incinta schitului, și atunci când se afla agentul «Macarovici» ca călugăr tot nu a putut să ne comunice din timp eventualele deplasări. Rugăm să ni se comunice ce materiale posedați dvs. referitor la Sandu Tudor și noi vom continua să stabilim deplasările conformându-ne ordinului dvs" $"$.

În aprilie 1958, cu mai puțin de două luni înainte de arestarea membrilor lotului „Rugului aprins”, o fișă biografică care-1 privea pe „Teodorescu Alexandru (Sandu Tudor), monahul Agaton, ieroschimonahul Daniil”, menționa cum, din anul 1955, ,a fost semnalat că are legături cu o serie de legionari de la mănăstirea Slatina din regiunea Suceava și de la Mitropolia Iași, printre care cu Anghel Papacioc, Roman Braga și alții”. Foarte important e că ,sub masca monahismului, toți aceștia sunt semnalați că desfășoară activitate legionară și intenționează să atragă în mănăstire elemente legionare care se eliberează din închisori pentru a fi călugăriţi. Sandu Tudor a reușit astfel să atragă în mănăstire pe legionarii Tudor Pavel, Larion Neagoe, Spiridon Roiu și Stoianovici Ion"11.

În paralel, se verificase deja și că:

„Sandu Tudor a reluat legăturile cu Benedict Ghiuş, Mironescu Alexandru și celelalte elemente cu care a activat în «Rugul Aprins», cu care se adună periodic la locuința profesorului Mironescu Alexandru din București și la diferite mănăstiri din Capitală, pentru a face educație mistică naționalistă, sub masca cultului ortodox, unui grup de studenți recrutaţi de aceștia din cadrul diferitelor facilităţi din București. În prezent, Sandu Tudor intenționează să-și lărgească cercul, atrăgând fie direct fie prin colaboratorii săi noi aderenți din rândul intelectualității antipopulare și a studenților" ${ }^{\prime 2}$.

${ }^{10}$ ACNSAS, Fond Informativ, dosar nr. 2214, vol. 1, f. 113-114.

11 ACNSAS, Fond Informativ, dosar nr. 2214, vol. 1, f. 94, 96.

12 ACNSAS, Fond Informativ, dosar nr. 2214, vol. 1, f. 96, 97. 
De la ziaristică la mistică:

identitatea creștină a lui Daniil Sandu Tudor

În noaptea de 13/14 iunie 1958, Daniil Sandu Tudor va fi arestat; după el, în aceleași zile, vor fi arestați și restul membrilor lotului, iar ancheta lor, conform datelor menționate în procesele verbale de interogatoriu, avea să se întindă pe toată vara lui $1958^{13}$. Sentința a fost pronunțată în luna noiembrie, iar Daniil Sandu Tudor este încarcerat la Aiud, unde avea să moară pe 17 noiembrie 1962.

\title{
2. Identitatea creștină și scrierile mistice ale lui Daniil Sandu Tudor
}

Dincolo de imaginea livrată de documentele Securității, cum arăta creștinul și monahul Daniil Sandu Tudor? Portretul cel mai pătrunzător i-l face lui Sandu Tudor bunul său prieten, Alexandru Mironescu:

\begin{abstract}
„Pentru cei care nu 1-au cunoscut bine, Sandu Tudor a fost mereu un element de scandal și un interminabil prilej de defăimare. Dar el era, în intimitatea sa, exact altceva decât ceea ce se spunea despre el. Era însă, e adevărat, un om greu, foarte greu, uneori, de suportat, și pentru unii profund dezagreabil, printr-un fel direct de a vorbi, fără menajamente, și aș zice fără nici o ipocrizie. Ferice însă de cei care îl puteau suporta: era atunci un prieten neprețuit și un om admirabil, de o nesfârșită delicatețe sufletească, de o mare originalitate. Știa multe lucruri, și în anumite domenii era un învățat, avea o informație de savant. Dar se și ascundea, iar printr-un fel dur de a fi, se apăra de oameni și - curios! - de admirația lor, pe care sigur ar fi putut-o avea"14.
\end{abstract}

„Toată viața lui a abordat un număr mare de probleme, iar dacă manuscrisele lui s-ar păstra, ele ar oferi un material de o

${ }^{13}$ ACNSAS, Fond Penal, dosar nr. 202, vol. 1 și 2.

${ }^{14}$ Alexandru Mironescu, Floarea de foc, București, Edit. Elion, 2001, p. 193-194. 
valoare excepțională”, mai nota Mironescu în „Floarea de foc"15. Totuși, multe din manuscrisele lui Sandu Tudor s-au păstrat, și de câteva din ele ne vom ocupa în cele ce urmează, urmărind în ele câteva din ideile referitoare la rugăciune, de vreme ce rugăciunea sa aflat în centrul preocupărilor Rugului Aprins. Fragmentele următoare provin din manuscrise ale lui Daniil Sandu Tudor, păstrate de preotul Niculae M. Popescu, și publicate sub îngrijirea editorială a lui Alexandru Dimcea ${ }^{16}$, acoperind cronologic perioada 1938-1958 (aşa numitele „caiete”).

La ieroschimonahul Daniil, studiul se împletește cu experiența rugăciunii „necurmate”, și din această perspectivă caietele sale de însemnări scot la lumină preocupările legate de Dumnezeu, rugăciune; gândiri despre Dumnezeu, rugăciune, dragoste, bucurie, păcătoșenie, starea lumii, Dumnezeu şi lumea, Sfânta Treime, Taina Crucii, rugăciune şi euharistie ş.a. Manuscrisele sale, extinse pe perioada 1938-1958, spun despre el următoarele:

„Toate textele rămase de la dânsul arată că era pe deplin lămurit. Credea. Ştia. Îşi descoperea mereu doar confirmări a ceea ce ştia dinainte. Era sensibil la orice subtilitate spirituală. $\mathrm{O}$ sesiza imediat. Toate lecturile lui sunt bine organizate, bine alese. Şi de peste tot îşi făcea note.

Nu mai știi azi, răsfoind atent caietele lui, cât e traducere din diferite lecturi, cât e parafrază, rezumat, glosă, gândire personală. A descifra aceasta ar însemna a parcurge tu însuţi toate lecturile lui şi a identifica sursele. (...) Nu-1 interesa erudiţia şi nu-şi făcea note pentru lucrări, ci pentru lucrarea interioară, în sensul isihast al cuvântului" ${ }^{17}$.

Caietele cuprind însemnări variate, de la meditații pe baza unor versete, la fragmente din lecturi care 1-au impresionat sau

${ }^{15}$ Ibidem.

${ }^{16}$ La editura Christiana.

${ }^{17}$ Antonie PlăMĂDEALĂ, Rugul aprins, Sibiu, Edit. Arhiepiscopiei Sibiului, 2002, p. 10. 
De la ziaristică la mistică:

cărora le găsește echivalențe în propria trăire. De la mistică la dogmatică, la morală. Problemele atinse cuprind rugăciunea, atributele ei, descrieri ale trăirilor sufletești, rugăciunea din inimă, rugăciunea neîncetată, problema omului ${ }^{18}$, Sfânta Cruce $^{19}$, problema Prezenței.

Am selectat câteva din gândurile şi meditaţiile sale despre rugăciune - în general, rugăciunea pornită din inimă şi Rugăciunea necurmată/,Sfințita Rugăciune” (Rugăciunea lui Iisus); ne-am oprit totodată asupra ceea ce am considerat a fi „,indicații” de „tehnică” pentru Rugăciunea necurmată, călătoria spre locul inimii, legătura liturghie-taină-inimă şi, nu în ultimul rând, ideea prezenței care apare în scrierile sale - dar apare şi ca moștenire spirituală la Părintele Sofian Boghiu ${ }^{20}$ sau Părintele Arsenie Papacioc ${ }^{21}$.

Mai întâi, un argument pentru „călătoria spre locul inimii” şi pentru centralitatea ei ca şi ,unealtă” de împreună-grăire cu Dumnezeu, ca şi poartă de exprimare a întregii ființe în rugăciunea vie şi experiența lui Dumnezeu:

„Omul nu poate trăi fără minune. Dacă n-o are, se minte pe sine că o are şi se amăgeşte, se înşală pe sine şi pe ceilalţi. (...) Azi, toţi am ajuns căutători de astfel de jumătăţi de adevăr, suntem atraşi de dulceagul romantism modern, artificial şi ameţitor.

Totuşi, mărgăritarul de înalt preţ, comoara cea adevărată ne este aproape. O lume înmormântată, o libertate uitată ce dormitează în propriul nostru suflet. Ţara aceea de farmec şi de uimire, pe care o căutăm în tot ce-i depărtat şi străin, în

18 Textele legate de această problemă au fost grupate şi publicate în cel de-al patrulea volum al Caietelor ieroschimonahului Daniil, Ce este omul?, Bucureşti, Edit. Christiana, 2003.

${ }^{19}$ De asemenea, însemnările grupate în volumul 3 al Caietelor: Taina Sfintei Cruci, Edit. Christiana, 2003.

${ }^{20}$ George CĂBAȘ, Pagini de pateric românesc, Bucureşti, Edit. Anastasis, 2011.

21 http://www.razbointrucuvant.ro/2011/07/21/cum-sa-ne-rugam-ne-invata-canimeni-altul-parintele-arsenie-papacioc-avem-nevoie-de-o-prezenta-continua-ainimii-asta-este-esenta-rugaciunii-si-video/ (accesat la 10.06.2014). 
exotic, frumuseţea încântării şi minunii o aflăm în preajma noastră, în viaţa de toate zilele, dar mai ales în noi înşine, în inima noastră"'22.

„Ca să cunoşti Adevărul cel viu trebuie tu să fii viu adevăr. $\mathrm{Nu}$ putem cunoaşte ceea ce nu ne este comun. Numai fiind tu în adevăr poţi cunoaşte adevărul"23.

Şi de aceea, ,se cere o întreagă călătorie spre locul inimii, pentru ca prin smerenie şi nevoinţă să intrăm prin Poarta cea strâmtă în Împărăția lui Dumnezeu" ${ }^{24}$. Motivul care orientează acest drum e că ,această desfăşurare pe firul cel întors al semnului Crucii, această călătorie, ea însăşi în sine, este o parte din Adevăr. Fiecare pas pe Calea cea sfântă este o agonisire din Adevăr. Şi calea la Adevăr însăşi e o parte însemnată din adevăr. „Eu sunt Calea, Adevărul şi Viaţa", iată treptele întrupării lui Hristos în noi" ${ }^{25}$. Mai mult, ,inima omului este dumnezeiască, ea cuprinde „Impărăţia Cerurilor" - prin urmare, de fapt, călătorind spre locul Inimii, descoperim la sfârşitul ei ,taina începuturilor”: ,şi peste faţa adâncului (abisului) de ape este întuneric şi Duhul lui Dumnezeu se mişcă deasupra apelor". (...) Aşa, prin minune lăuntrică, omul descoperă, cu înfiorare, caracterul abisal al inimii lui" 26 . Însăși „mântuirea este această scoborâre a Logosului în Abisul cel mai de jos, a Minții în Inimă"27.

Ideea de coborâre a minţii în inimă se aflase constant între preocupările părintelui Daniil, după cum ilustrează grăitor aceeași notă informativă din decembrie 1949, care detalia predica de joi seara de la mănăstirea Antim:

22 Daniil Sandu Tudor, Taina Rugului aprins. Scrieri și documente inedite, ediție îngrijită și cuvânt înainte de prof. Gheorghe Vasilescu, București, Edit. Anastasia, 1999, p. 34.

23 Ieroschimonahul DaniIL, Caietele: 1. Dumnezeu-Dragoste, Bucureşti, Edit. Christiana, 2003, p. 136.

${ }^{24}$ Ibidem, p. 36-37.

25 Ibidem, p. 137.

${ }^{26}$ Ibidem, p. 29-30.

${ }^{27}$ Ibidem, p. 30. 
De la ziaristică la mistică:

identitatea creștină a lui Daniil Sandu Tudor

„Pr. Agaton împreună cu Benedict Ghiuş care de altfel a fost profesor la catedra de Mistică la Facultatea de Teologie din Bucureşti, voiesc ca să propage această mistică în rândul clericilor. Această „mistică” este pe cale ortodoxă, ea însă aparţine călugărilor şi în special călugărilor care trăiesc în mănăstiri sau pustietăţi. Preotul Agaton a vrut să arate în predică că numai cine are această mistică tainică, cine coboară mintea în inimă, numai acela este un om integru (s.n., I.U.). Toate acestea formează după propria expresie „trupul mistic al lui Cristos". Unii ca aceștia, convinși fiind până în adâncul fiinţei despre fericirea ce o primesc de la Cristos, sunt în stare să-1 mărturisească pe Cristos cu atâta îndrăzneală încât să devină martiri. Cei ce nu-1 au pe Cristos în inimă nu au o viaţă mistică şi de aceea nu cred în Dumnezeu" ${ }^{28}$.

Adevărata rugăciune porneşte din inimă:

„Fără îndoială, o adevărată rugăciune nu poate fi decât o rugăciune a inimii. Nu e vorba aici de o simplă rugăciune formală, de pravilă, de plinirea superficială a unui fel de datorie, de convenţiune religioasă. Spunerea rugăciunii, recitarea rugăciunii, făcută cu destulă sinceritate, rămâne de cele mai multe ori străină de centrul adevărat al firii noastre, mai ales când acest vârf al sensibilităţii noastre religioase e ofilit sau împietrit de păcat. $O$ astfel de rugăciune nu are altă urmare decât a pricinui în aerul înconjurător nişte vibraţii mai mult sau mai puţin sonore $^{29}$. (...) Rugăciunea, oricare ar fi ea, trebuie necurmat şi limpede, să ţâş̧nească întreagă numai din inima omului. Altminteri ea este sunet gol de chimval zadarnic sau vorbă mincinoasă" ${ }^{30}$.

${ }^{28}$ ACNSAS, Fond Informativ, dosar nr. 2214, vol. 5, f. 301.

29 IERoschimonahul Danill, Caiete: 2. Sfinţita Rugăciune, Bucureşti, Edit. Christiana, 2003, p. 44.

${ }^{30}$ Ibidem, p. 45-46. 
De la rugăciunea pornită din inimă, cum se lucrează sau cum se ajunge la rugăciunea neîncetată sau necurmată? Ieroschimonahul Daniil atrage atenția la această creştere în plan duhovnicesc:

„Trebuie să ajungi la acea treaptă a creşterii tale duhovniceşti, când nu mai e nevoie să te rogi într-un anumit chip şi loc, la o anume vreme şi după o anumită rânduială de canon sau metodă $\breve{3}^{31}$. Adică să te liberezi de sarcina rugăciunii, ceea ce înseamnă să te învredniceşti să fii până întru atâta stăpân pe rugăciunea ta, sau, mai bine, stăpânit de rugăciune, încât tu să-ţi trăieşti starea de rugăciune ${ }^{32}$. Unul ca acesta nu-şi mai face rugăciunea, ci este el însuși, cu întreaga lui făptură, numai rugăciune. Către acest stadiu ne îndeamnă să ne străduim, Scripturile, când ne spun «Rugaţivă neîncetat»" ${ }^{\prime 3}$.

Această stare se caracterizează prin aceea că:

„Rugăciunea nu mai este făcută numai cu buzele, nici chiar numai cu gândul. Omul de rugăciune o trăiește într-o puternică unitate cu sufletul şi cu trupul său la un loc. Această rugăciune totală nu mai este nici rugăciunea cugetului meu, nici rugăciunea inimii mele, ci ea este întâlnirea polară a acestor două, prin ceea ce se numește «introducerea minții in inimằ). Această rugăciune integrală este rugăciunea duhovnicească. $\mathrm{Nu}$ ne mai rugăm nici cu sufletul, nici cu trupul, nu ne mai rugăm noi, ci Duhul se roagă în noi”34. Aceasta e ,rugăciunea cea necurmată, care nu are nimic cu timpul, ci ea e rugăciunea veșnică a Duhului (...) este rugăciunea cea neîncetată, care ne cântă în gând, ne aleargă în sânge, ne bate în inimă, fiecare zvâcnire a răsuflării noastre de-a pururea în noi şi chiar dincolo de noi, ca un dar neîntrerupt al Duhului Sfânt, încât putem spune

${ }^{31}$ Ibidem, p. 69.

${ }^{32}$ Adică o stare de prezenţă, cum vom vedea.

${ }^{33}$ Ibidem, p. 70.

${ }^{34}$ Ibidem. 
De la ziaristică la mistică:

identitatea creștină a lui Daniil Sandu Tudor

precum mireasa fecioară a Cântării Cântărilor: «Eu dorm, dar inima mea vegheazăı"»"

În ce privește rostirea ei, ieroschimonahul Daniil Tudor indică condițiile pe care sufletul şi le impropriază pe măsura înaintării în rugăciune. Astfel, ,,cea dintâi condiție a rugăciunii este acordarea cu noi înșine. Liniștire, destindere și luarea de atitudine. (...) Aceasta ne învață Sfântul Ignatie Teoforul în chip minunat în Epistola către Filadelfieni când spune: «Admir - mă plec cu încântare uimită față de - blândețea acestuia, care, tăcând, poate mai mult decât alții care vorbesc cu zadar, fiindcă el se află în acord cu poruncile Domnului, așa precum alăuta cu coardele sale»" "36.

Apoi, lacrimile. Între numeroasele lecturi filocalice ale părintelui Daniil se numără şi Evagrie Ponticul, al cărui Cuvânt despre rugăciune îl tradusese în 1946, la Antim ${ }^{37}$. Astfel, notează el, „Evagrie pune ca întâia condiție a rugăciunii lacrimile: «Mai întâi roagă-te pentru dobândirea lacrimilor, ca prin plâns să înmoi sălbăticia ce se află în sufletul tău; şi după ce vei fi mărturisit aşa, tu împotriva ta, toate fărădelegile tale înaintea Domnului, să primești iertare de la El» (Cele 153 de cuvinte despre Rugăciune, Cap. 5)"38. Mai apoi:

„Prin repetarea rugăciunii, mai întâi trebuie învinse josnicia, scârboșenia proprie, urâțenia, uscăciunea din mine $^{39}$ pe care le credeam înecate în adâncimea cea mai profundă a refuzului meu; zădărnicia, deșertăciunea mea pe care inepţia o leagănă într-o îndârjită obsesie, îndărătnicie, tăgăduire ascunsă; îndeosebi, mai grozavă

${ }^{35}$ Ibidem, p. 70-71.

${ }^{36}$ Ibidem, p. 33-34.

${ }^{37}$ Ibidem, p. 202-234.

${ }^{38}$ Ibidem, p. 33-34.

39 Spre deosebire de literatura „duhovnicească” similară care folosește, fie, impersonal, persoana a III-a, fie, familiar, persoana a II-a, folosirea constantă a persoanei I singular este o marcă a acestor însemnări - atunci când ele fac referire la experiența personală a rugăciunii - şi mai ales la lipsurile şi obstacolele sufletești - expresie a smereniei. 
decât toate celelalte, răceala, asprimea, nelegiuirea, împietrirea mea faţă de nedibăcia faţă de mine însumi cel adevărat şi faţă de toate, şi mai ales faţă de Dumnezeu. Frumuseţea rânduielii, când ea ajunge a elibera sufletul, a-1 conforma desăvârşirii prin curata rugăciune pre aceasta o caută, cele dinafară toate i se par pângărite şi urâte. Şi se cade a te învăţa la aceasta, „Că acolo aflându-se mintea, dator eşti de atunci încolo a n-o lăsa pe dânsa să tacă şi să stea nelucrătoare ci dă-i ei pre: «Doamne Iisuse Hristoase Fiule al lui Dumnezeu, miluieşte-mă!»" ${ }^{40}$.

Transformarea lucrată în suflet în urma rostirii rugăciunii se petrece tainic, dar simţit. Chiar dacă:

„La început nu desluşeşti nimic în această nesfârşită repetare de sunete în care este închis Numele. Însă îndată ce gândeşti altminteri decât pe din afară, se petrece cu tine o situaţie minune: începi să simţi în apropiere o inimă care te iubeşte, care nu oboseşte să te asculte. Îţi dai seama că singură mediocritatea mea, sărăcia de daruri a dragostei mele prea scoborâte, lipsa de putere de a ţâşni din nou cât mai sus, neregularitatea mea, teama, grija de a te pierde pe tine însuţi, zgârcenia de sine însuşi care mă închide în mine, mă lipseşte de puterea de a alerga din nou la singurul mijloc de a chema şi apropia, şi care e precis această încântare de dor care cheamă această litanie nesfârşită, această întoarcere necurmată, această roată heruvică de cuvinte care te roagă pe tine însuţi fierbinte şi cu duh nestins de dreaptă slăvire şi dragoste" 41 .

Pe lângă aceste conştientizări ale păcătoşeniei şi nimicniciei, Rugăciunea rezervă şi momente deosebite de har:

„Deosebitele vădiri ale «Rugăciunii duhovniceşti» au toate un caracter comun: străfulgerarea dintr-o dată a Harului. În timpul cântării unui psalm, la auzul unei cuvântări

\footnotetext{
${ }^{40}$ Ibidem, p. 29-30.

${ }^{41}$ Ieroschimonahul Danill, Caiete: 2. Sfinţita Rugăciune, p. 29.
} 
De la ziaristică la mistică:

identitatea creștină a lui Daniil Sandu Tudor

duhovniceşti, la moartea cuiva mult iubit sau la vremea unei cugetări mai adânci asupra căldicelului şi risipirii şi lâncezirii din neorânduială, călugărul simte sufletul său aprinzându-se brusc, dintr-o dată lumina cea cerească îl inundă, simţăminte de pocăinţă îl năpădesc, şi rugăciunea se înalţă spre Dumnezeu în ţâşniri de foc"42.

În acelaşi plan şi în strânsă legătură cu trăirea rugăciunii inimii, părintele Daniil dezvoltă câteva repere pentru o teologie a prezenţei. Ideea are mai multe valenţe, în funcţie de persoana/Persoana din actul rugăciunii. Mai întâi, este vorba de atenţie, conştientizare, raportare la Dumnezeu în momentul rugăciunii: „Prima condiţie esenţială a rugăciunii e deci de a ne pune în prezenţa lui Dumnezeu, de a sta în faţa lui Dumnezeu"43. Apoi, este vorba despre felul în care Dumnezeu se face simţit, îşi face cunoscute în mod natural lucrările: „Nevăzut este Domnul Dumnezeu; dar prezenţa Lui e universală şi cu totul în vileag. Aşa încât nicio făptură vie şi cugetătoare nu poate spune (...) că se află lipsită de bucuria cea limpede a cunoaşterii şi re-cunoaşterii Lui depline şi de toată clipa. Nevăzut este Domnul Dumnezeu, dar toată mintea şi semnele Lumii au fost anume făcute ca să-L vadă şi să-L vădească pururi. Toate făpturile şi toate lucrurile, toată huma şi toată umbra stau cu greutatea şi taina lor întreagă, ca o înaltă Parabolă a cunoaşterii Lui de taină" ${ }^{\prime 4}$.

„Trăirea lăuntrică, rugăciunea şi simţământul” fac ca această prezenţă dumnezeiască să fie simţită limpede, conştient, precis ${ }^{45}$. Totuşi, „Prezența Dumnezeiască, realitate imediată şi numai ca atare întemeietoare a evlaviei, nu va fi recunoscută decât de om, pus în măsură de a constata la el puterea creatoare" ${ }^{46}$. Deşi omul simte ,toată firea [ca] o transparenţă a acestei prezenţe" (...), ea „nu e toată prezenţa (...) mai e ceva. Mai e o descoperire

\footnotetext{
${ }^{42}$ Ibidem, p. 35.

${ }^{43}$ IDEM, Caiete:1. Dumnezeu-Dragoste, p. 36.

${ }^{44}$ Ibidem, p. 98.

45 Ibidem.

${ }^{46}$ Ibidem, p. 107.
} 
şi o trăire a Prezenţei directe, duh către Duh, care e revelaţia fundamentală, cuminecarea duhovnicească a Chipului" ${ }^{47}$. Se înţelege astfel identitatea esenţială dintre simţul Prezenței lui Dumnezeu şi Sfânta Întrupare. „Nu o prezenţă în lucruri şi locuri, în idol, în mit, ci în chip viu, Dumnezeul cel viu" ${ }^{48}$, cunoaşterea lui Hristos din Evanghelii, viu, prezenţa Sfântă ${ }^{49}$. Mijloacele de conştientizare a acestei Prezenţe sunt, în primul rând, Scriptura şi Tradiţia Bisericii. Apoi, ,profeţii şi sfinţii, care ne arată drumul pe care se va întâmpla şi nouă Marea întâlnire, cu noi înşine şi cu Dumnezeu" ${ }^{\circ 0}$. Mai apoi, religiozitatea Prezenţei se cultivă şi prin descoperirea înţelesului teofanic al propriei vieţi, prin duhovnic şi liturghie $^{51}$. De fapt, întreaga viaţă are un sens teofanic, adică e liturghie, arătarea continuă a prezenței de taină a lui Dumnezeu ${ }^{52}$.

„Prezența lui Dumnezeu e o problemă de experiență, de trăire, de reală intervenție dumnezeiască" ${ }^{\prime \prime 53}$, adică reclamă necesitatea imperioasă a unei teologii vii, a experienței, ,adică descoperirea prezenței, adică să trecem prin drama nașterii cea de a doua, a luptelor interioare, biruindu-ne propria natură, învingând piedicile de gândire și viaţă proprie, umbrite sau la umbra Duhului Sfânt" 54 , căci ,trebuie să salvăm evlavia trăită integral, duhovnicia, viețuirea în Har"55. Legătura acestei teologii a prezenței lui Dumnezeu cu rugăciunea inimii se exprimă în experiența Prezenței care trebuie să fie o condiție sine qua non a Rugăciunii. Atenția iubitoare la Dumnezeul prezent, un simplu act de credință în Dumnezeul prezent îi aduce rugăciunii inimii putința de a fi numită „rugăciunea de simplă prezență a lui Dumnezeu”56. Rugăciunea

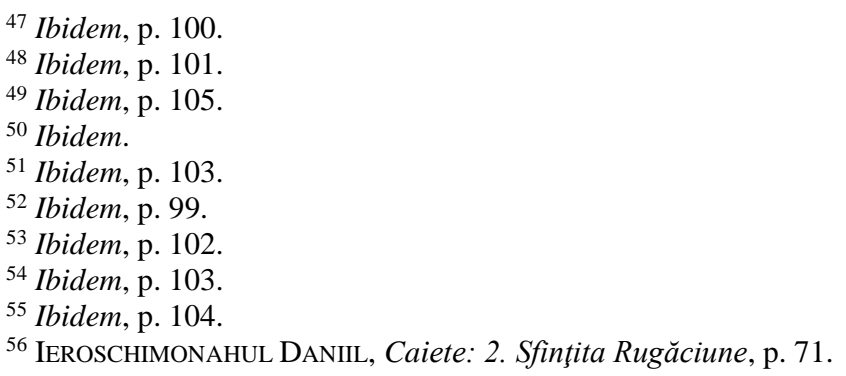


De la ziaristică la mistică:

identitatea creștină a lui Daniil Sandu Tudor

inimii și o teologie a ,prezenței” se întrepătrund astfel într-o experiență vie şi nemijlocită a lui Dumnezeu.

\section{Concluzii}

Manuscrisele lui Daniil Sandu Tudor ne relevă un gânditor mistic de o forță extraordinară, ancorat în Tradiția creștină și de o extraordinară luciditate. Am optat pentru redarea extensivă a tuturor aceste fragmente de însemnări spirituale pentru a le juxtapune documentelor Securității care redau o imagine „dușmănoasă”, de „uneltitor” împotriva statului. Deși am notat în repetate rânduri cum activitatea tuturor oamenilor legați cu numele de „Rugul aprins” era eminamente spirituală, „lupta ideologică împotriva comunismului", așa cum apare ea reluată ca motiv și temă în dosare, trebuie înțeleasă în întregul ei conținut, și acest conținut se referă inclusiv la trăirea mistică creștină, așa cum ne-o indică însemnările lui Sandu Tudor.

0380

\section{Bibliografie}

\section{Arhive și literatură}

1. Arhiva Consiliului Național pentru Studierea Arhivelor Securității (ACNSAS): Fond Informativ, dosar 2214, vol. 1-2; Fond Penal, dosar 202, vol. 1-2.

2. CĂBAŞ, George, Pagini de pateric românesc, Bucureşti, Edit. Anastasis, 2011.

3. *** Caietele preacuviosului părinte Daniil de la Rarău (Sandu Tudor). Vol. 1: Dumnezeu-Dragoste, București, Edit. Christiana, 2000.

4. *** Caietele preacuviosului părinte Daniil de la Rarău (Sandu Tudor).Vol. 2: Sfinţita rugăciune, București, Edit. Christiana, 2000.

5. *** Caietele preacuviosului părinte Daniil de la Rarău (Sandu Tudor).Vol. 3: Taina Sfintei Cruci, Bucureşti, Edit. Christiana, 2001.

6. *** Caietele preacuviosului părinte Daniil de la Rarău (Sandu Tudor).Vol. 4: Ce e omul?, Bucureşti, Edit. Christiana, 2003. 
7. MironesCu, Alexandru, Floarea de foc, București, Edit. Elion, 2001.

8. Plămădeală, Antonie, Rugul aprins, Sibiu, Edit. Arhiepiscopia Sibiului, 2002.

9. PĂIUŞ̧An, Cristina / CiuCEAnu, Radu, Biserica Ortodoxă Română sub regimul comunist, 1945-1958, vol. I, Bucureşti, Institutul Naţional pentru Studiul Totalitarismului, 2001.

10. TUDOR, Daniil Sandu, Taina Rugului aprins. Scrieri și documente inedite, ediție îngrijită și cuvânt înainte de prof. Gheorghe Vasilescu, București, Edit. Anastasia, 1999.

\section{Surse web}

1. http://www.razbointrucuvant.ro/2011/07/21/cum-sa-ne-rugam-neinvata-ca-nimeni-altul-parintele-arsenie-papacioc-avem-nevoie-deo-prezenta-continua-a-inimii-asta-este-esenta-rugaciunii-si-video/ (accesat la 10.06.2014). 